\title{
Mediation analysis of environmental training: Perceived stakeholder pressure and environmental supply chain management practices
}

Awan, Usama

Lappeenranta University of Technology, Finland (usama.awan@lut.fi)

Received: 10 October 2016 Available Online: 9 November 2016
Revised: 22 October 2016 DOI: $10.5861 /$ ijrsm.2016.1656

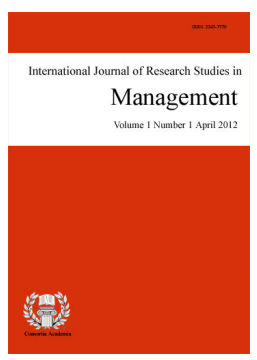

ISSN: $2243-7770$ Online ISSN: 2243-7789

OPEN ACCESS

\section{Abstract}

The purpose of this research is to examine the mediation role of environmental training in the relationship between perceived stakeholder pressure and implementation of the environmental supply chain management practices. A survey was administered to manufacturing firms and hypothesis was tested using structural equation modeling analysis. This research suggests that environmental training is mediates the relationship between stakeholder pressure and implementation of environmental supply chain management practices. The results suggest that managers perceive that stakeholder pressure and environmental training are important to themselves. In this study overall, market stakeholders had a stronger relationship with the implementation of the environmental supply chain practices than the regulatory stakeholders. The findings also indicate that stakeholder pressure is an essential driver for implementation of environmental supply chain management practices. This study is one of the first to investigate the relationship between the stakeholders' pressure and environmental supply chain management practices in manufacturing firms. The study also offers important implications for managers and partitions. Future research direction and limitation are also discussed.

Keywords: market stakeholders; non-market stakeholders; regulatory stakeholders; environmental supply chain management; environmental training 


\section{Mediation analysis of environmental training: Perceived stakeholder pressure and environmental supply chain management practices}

\section{Introduction}

Stakeholders' pressure is viewed as an essential component in decision making and implementation of environmental management practices (Tachizawa \& Wong, 2015) and green sustainable economy is urgent and essential (Rouf, 2013). Stakeholder pressure describe the degree of accountability in which an organization perceives held responsible for its action and decisions regarding design of product, production, sourcing or distribution to stakeholders (Parmigiani, Klassen, \& Russo, 2011). The potential of environmental training for the implementation of environmental supply chain practices has been widely acknowledged (Sarkis, Gonzalez-Torre, \& Adenso-Diaz, 2010).The research findings show that training plays an important role in implementation of environmental practices (Ahmad \& Schroeder, 2003). Future research is needed to understand the effectiveness of training on the implementation of the environmental supply chain management practices(ESCM) (Wong, Wong, \& Boon-itt, 2015). Inconclusive research findings into the nature of the relationship between the stakeholders pressure and implementation of environmental supply chain practices are exists (Hult, Mena, Ferrell, \& Ferrell, 2011; Eltayeb et al., 2011; Mitra \& Datta, 2014; Zhu, Sarkis, \& Lai, 2012).

Sialkot manufacturer have started experience of pressure from foreign customers and international regulator authorities during the years of 1994 from quality barriers when exporting their products to United States of America (USA). Federal Drug Authority (FDA) in 1994 ban sales to United States concern regarding the quality issues of Sialkot surgical instruments on grounds that low quality of metal composition standards and chromium content and hardness of stainless steel was below standard level. A number of large manufacturer sought new subcontracts in new markets of Asia and Southern Africa. After the 1994 Surgical Instrument Manufacturing Association (SIMA) made exclusive agreement with the FDA to provide training to their local producers to upgrade their good manufacturing practices standards (GMP standards USA) with the help of financial aid form government. Research into the environmental supply chain management practices are popular among the developed countries (Laosirihongthong, Adebanjo, Tan, \& Choon Tan, 2013; Odeyale, Oguntola, \& Odeyale, 2013). Little empirical evidence is available on better implementation of environmental practices throughout the supply chain sustainability from Asian perspective (Arlbjørn \& Lüthje, 2012; Mitra \& Datta, 2014). According to (Kanapathy, Yee, Zailani, \& Aghapour, 2016), drivers and mechanism that enable manufacturing firms to engage in environmental sustainability practices have not investigated in south Asian context. ESCM practices includes internal environmental management, green purchasing, cooperation with consumers, eco-designs, and investment recovery (Zhu, Sarkis, \& Lai, 2008).

The manufacturing industry under study is a leading industry which provides $6 \%$ trade value to the total gross domestic production to Pakistan. The Sialkot is well known in the world as a producer of the sports and surgical goods particularly. But the relationship between pressures and implementation of environmental supply chain management (ESCM) practices at this time is therefore not entirely clear and need more investigation in Asia (Zhu, Geng, Fujita, \& Hashimoto, 2010; Lee, 2016). Yet, little is known about engagement of stakeholders for implementation of environmental management practices (Meixell \& Luoma, 2015). This study respond to the call of (Betts, Wiengarten, \& Tadisina, 2015). Stakeholder theory and resource base view (RBV) are applied to test the hypothesis. Stakeholder theory is applied at the level of the stakeholder pressure influence the firms to actively implement the environmental supply chain management practices. Theory of stakeholder is well recognized and has been used in the supply chain management (Genovese, Lenny Koh, Kumar, \& Tripathi, 2013; Sarkis et al., 2010; Betts, Wiengarten, \& Tadisina, 2015). RBV suggest that manufacturing firms are more likely to implement practices, if their employees have capabilities and knowledge resources. A firm resources, capabilities and competencies are valuable assets (Barney, 1991). Resource base theory is focus on 
Mediation analysis of environmental training: Stakeholder pressure and supply chain management practices

inter-organizational learning and knowledge sharing practices in the environmental supply chain practice (Sarkis, Zhu, \& Lai, 2011). This study is an early attempt in the Asian perspective to test either environmental training can mediates the relationship between stakeholders' pressure and implementation of ESCM practices toward the use of the environmental training for the implementation of ESCM. The purpose of this research is to examine the mediation role of environmental training in the relationship between perceived stakeholder pressure and implementation of the environmental supply chain management practices.

The study addresses the following research questions:

$>\quad$ What are the important stakeholders for implementation of environmental supply chain practices?

$>\quad$ Does environmental training mediate the relationship between stakeholder pressure and adoption of green supply chain management practices?

However, this study differs from previous research because focus is on the determining pattern of stakeholder pressure for the environmental training and its effectiveness for implementation of environmental supply chain management practices.

\section{Literature review and hypotheses development}

\subsection{Theoretical-Resource Base View}

This study employs both stakeholder theory Wicks, Gilbert, and Freeman (1994) and Resource Based View RBV (Barney, 1991) to develop theoretical framework and test the hypothesis. The stakeholder theory examines the pressure influence on the firm and in response implements these practices. Firms resources have been defined "as all assets, capabilities, organizational processes, firm attributes, information, and knowledge controlled by an enterprise that enable the firm to implement strategies" (Barney, 1991). Capabilities are rooted into the business process and indicate the organizational competencies (Birkinshaw, Hamel, Mol, \& Vaccaro, 2008). Using Stakeholder theory and RBV offers useful explanation how these effects the firm performance (Sambasivan, Bah, $\&$ Ho, 2013). The present study will use multi-theoretical lens for testing the hypothetical framework and Joint theoretical understanding is valuable to the environmental management practices in operations (Sarkis et al., 2010).

\subsection{Stakeholders and Environmental Supply Chain Management Practices}

\section{Development of Hypotheses}

According to (Donaldson \& Preston, 1995) suggests stakeholders are organizational actors and decision making is the central of this theory. Each actor has some legitimate power to influence the firm performance or has stakes in the firm performance (Freeman, Harrison, Wicks, Parmar, \& Colle, 2010) and have different expectations, objectives and responsibilities (Clarkson, 1995). According to Zhu et al. (2008) and Sarkis et al. (2010) internal and external practices. Internal practices include implementation of environmental management programs, investment recovery, and external practices include green purchasing, cooperation with customers. The present study follow the definition of (Zhu, Sarkis, Cordeiro, \& Lai, 2008) for internal and external green supply chain management practices. Environmentally sustainable supply chain management (ESCM) or GSCM practices are interchangeably terms which have been addressed in the academic literature (Carter \& Easton, 2012; Giovanni, 2012; Rao \& Holt, 2005; Wu \& Pagell, 2011; Zhu, Sarkis, \& Lai, 2012).

Stakeholder pressure is a key determinants (Liu, 2009) and it has resulted in motivating the firms for the implementation of environmental related practices in to their supply chain (Sarkis et al., 2010). A variety of primary and secondary stakeholders include: regulatory pressure, customer specific requirement, consumer pressure (Björklund, Martinsen, \& Abrahamsson, 2012), competitors (Sarkis et al., 2010), employees and 
Awan, U.

investor pressure (Walker, Di Sisto, \& McBain, 2008) creates pressure. Market Stakeholders have much ability to influence on adoption environmental pressure such as customers and clients (Zhu et al., 2005) than the non-market stakeholders public consciousness and government regulations for environmental protection (Sharma \& Henriques, 2005; Zhu et al., 2012).Customers are foremost important stakeholders (Foley et al., 2005). Similarly (Palmberg \& Garvare, 2006) proposes customers are important and likely to influence the firm environmental strategy (Ageron, Gunasekaran, \& Spalanzani, 2012). Specifically export market and international suppliers are main antecedents that may motivate the firm to adopt ESCM practices (Ehrgott, Reimann, Kaufmann, \& Carter, 2011). Regulatory support and pressure is important (Azizullah, Khattak, Richter, \& Häder, 2011; Ageron et al., 2012).

The research findings of Chien and Shih (2007) shows that various stakeholders such as (competitors, suppliers, supply chain partners, community, government regulations and media) are important driving force. Moreover, Sarkis et al. (2010) also emphasized that stakeholder pressure is positively associated with the implementation of GSCM practices but the environmental training programs may facilitate for its effectively implementation. Further (Srivastava, 2007) also pointed out that customers and suppliers are key drivers; community pressure is positively associated (Zhu et al., 2008); Domestic regulatory pressure is positively associated (Zhu et al., 2012; Diabat \& Govindan, 2011). Foreign partner of supply chain, can also influence on firms to comply with the international environmental standards (Zhu et al., 2008) and is essential for the improving citizen life live and to safe planet (Rouf, 2013). This study followed the (Clarkson, 1995) classification scheme of primary and secondary stakeholders. Market stakeholders (primary) are those who have direct contract with the business (engage in economic transaction) and essential for the business to exit. Further (Delmas \& Toffel, 2010) proposed a conceptual model how group of stakeholders such as market and non-market stakeholders influence on the firms.

The following hypothesize is posited:

$>$ H1: There is a positive relationship between (H1a) Market stakeholders; (H1b) Non-market stakeholders; (H1c) Regulatory stakeholders' pressure and the implementation of internal environmental supply chain management practices.

\section{External Green Supply Chain Management Practices}

External environmental activities related to cooperation and integrating with supply chain partner and sourcing renewable material. It defined as direct involvement of firm for jointly planning for ESCM practices with its suppliers and customers (Vachon \& Klassen, 2006; Yan, Chien, \& Yang, 2016). Green purchasing includes all the activities aims to ensure that purchased items must have environmental friendly attributes such as recyclable, reusable and absence from the hazardous material (Carter \& Carter, 1998; Zhu et al., 2012). For successfully implementation of the green practices into their operations that must have green selection criteria for the suppliers. Green purchasing defined "an environmentally-conscious purchasing practice that reduces sources of waste and promotes recycling and reclamation of purchased materials without adversely affecting performance requirements of such material" (Carter \& Carter, 1998; Zhu et al., 2012).

Stakeholder pressure is a key determinant ( Liu, 2009) and driver which a firm may compliance (Zhu et al., 2012). Pressure from different institutions such as customer environmental pressure, government regulations and competitive pressures has been considered important driver (Ramirez, Gonzalez, \& Moreira, 2014; Ageron et al., 2012). The research findings of (Sarkis, Gonzalez-Torre, \& Adenso-Diaz, 2010) support the idea that greater pressure a firm perceive from the international buyers and suppliers greater the firms consider the environmental friendly practices into their operations. Research has shown a heterogeneous impact on entire green supply chain (Tsai \& Hung, 2009). Employees, customers, government, NGOs are perceived important drivers for implementation of social responsible practices (Ditlev-Simonsen \& Wenstøp, 2013).

Business Suppliers, community, non-profit organization, top management and government regulations 
(Gunasekaran \& Gallear, 2012). Domestic regulatory pressure (Zhu et al., 2012), government regulations (Diabat \& Govindan, 2011), Foreign partner of supply chain and international environmental standards (Zhu \& Sarkis, 2007), special interest groups, community, regulations, customers, employees and union (Bhattacharya et al., 2014)are significantly influence for implementations. The research findings of (Wolf, 2014) comprised on relationship between stakeholder pressure and supply chain management practices and its impact on the corporate sustainable performance. in addition to this, (Zhu et al., 2012) suggests that firms cooperate actively with the customers with customer and regulatory pressure for eco-design and green manufacturing respectively. For internal management practices such as waste reduction and recycling government regulations are important (Zhu, Tian, \& Sarkis, 2012; Odeyale et al., 2013).

Most firm in South Asian take into account environmental consideration into purchasing due to the international laws and consumer pressure (Walker et al., 2008). Based on discussion, the following hypothesis is formulated:

> H2: There is a positive relationship between (H2a) Market stakeholders; (H2b) Non-market stakeholders; (H2c) Regulatory stakeholders' pressure and the implementation of external supply chain management practices.

\section{Environmental Training Effect on Adoption of ESCM Practices}

Training, which focuses on approaches to build knowledge resources and developing and maintain skills for successful exchange (Sarkis et al., 2010). According to (Teixeira, Jabbour, de Sousa Jabbour, Latan, \& de Oliveira, 2014) implementation of environmental practices require internal orientation at a first stage and (Giovanni, 2012) affirms that evolution of in house environmental management training is dependent on the firm environmental orientation. However (Mohanty \& Prakash, 2013) confirmed that training is particularly important for improvement of internal operations. For implementing, environmental related practices in supply chain a firm needs to start with development of the employees' capabilities through training. There is also need to examine whether it mediates the relationship between stakeholder pressure to the adoption of green practices in other industries and countries have the same significant impact to firm environmental practices (Sarkis et al., 2010).

The research study of (Paauwe \& Boselie, 2003) provides an evidence that regulatory pressure is a driving source to provide training to the employees (Esteban-Lloret, Aragón-Sánchez, \& Carrasco-Hernández, 2014). The reason to provide training to managers may benefit the organization in terms of increasing efficiency. Management could take initiate on implementation of environmental training program by giving specifically focus on building knowledge about the analyzing composition of material (Lee, Klassen, Furlan, \& Vinelli, 2014). The support of industry association is vital for those firms wanted to enhance environmental management through training initiatives (Jabbour \& De Sousa Jabbour, 2016).A strong and positive relationship exists with the training as a mediator has direct effect on the eco-design. Training is also a pre-requisite for implementation of the environmental management system (Sarkis et al., 2010). Media might not play a role to invest in the environmental training programs that may help to implement environmental practices (Sarkis et al., 2010).As a result of external pressure, training is considered an important part of the environmental management agenda in operations management research field (de Sousa Jabbour et al., 2013; Jabbour \& De Sousa Jabbour, 2016) and still continues an evolving field of research (C. J. C. Jabbour \& De Sousa Jabbour, 2016). Therefore, it is argue that environmental training program implemented by the firms experiencing pressure from different stakeholders for the implementation of green supply chain management practices have a mediating impact on the relationship between the stakeholder pressure and implementation of green supply chain management practices. The following hypothesis is formulated:

> H3: There is a positive relationship between (H3a) market stakeholders; (H3b) non-market stakeholders; $(\mathrm{H} 3 \mathrm{c})$ regulatory stakeholders' pressure and the implementation of environmental training. 
$>$ H4. Environmental training significantly mediates the relationship between the (H4a) market stakeholders; (H4b) non-market stakeholders; (H4c) regulatory stakeholders and implementation of internal green supply chain practices

\section{Control Variables}

We control the firm's age, size and industry type in order to test our hypothesized model still hold even after controlling the effect of these variables. Becchetti and Santoro (2001) argue that the firm experience in is significantly affect the firm export process. Large firms have often support from the foreigner investors and have better abilities and resources to reduce the environmental impact (Melnyk, Sroufe, \& Calantone, 2003). Similarly many previous studies have control firm size in their analysis such as (González-Benito \& González-Benito, 2010; Melnyk et al., 2003). To ensure the credibility and robustness of results, the present studies will control a number of contextual variables and extraneous variables that may affect the results of the study such as number of employees (firm size), firm ownerships and participated in green interested association are in line with the previous studies (Eltayeb, Zailani, \& Ramayah, 2011). According to the Diane and Abby (2009) that small and medium size enterprisers feel less influence from external forces to adopt the green operations practices.

\section{Research Methodology and Design}

The manufacturing industry of Sialkot is look appropriate for this study because according to the Government of Punjab, Sialkot sector industry account for the $6 \%$ of the total exports of Pakistan. Sialkot region is serving foreign customers with a wide variety of products and this single city accounts for the $70 \%$ of the world soccer balls (hand stitch) supplies with 35 million production. Pakistan still world second largest suppliers of machine made balls and exporting 13\% of the world total demand of sports ball (Trade Fair, 2011).

The population frame for present study consists of manufacturer export firms from Sialkot, Pakistan. In this present study an individual firm is considered as a unit of analysis. Before, implementation the questionnaire for data collection, survey instrument was pretested with twenty managers of the ISO14001 manufacturers for assessing readability and completeness (Dillman, 2011).Based on the suggestion few items were modified to the final construct. The measurement items were adopted from the existing tested scales. However the items were modified according to the local industry standards. The sampling frame for this study was developed from the list registered exporters drawn from the Sialkot chamber of Commerce Industry. Sample was drawn randomly from the list in line with the previous research studies (Zhu et al., 2012). The key respondents were selected from firm. This type of data collection methodology has been used in research studies. The knowledgeable key respondents were selected in order to meet the objective of the study and most of the respondents were belong to the operations and production functions (Gonzalez-Benito \& Gonzalez-Benito, 2006).

Of the 1100 manufacturing firms belong to different industrial sector, 288 completed questionnaires were received. Out of which 16 questionnaires were discarded due to incomplete information and 272 useful questionnaires were found satisfactory and response rate was $26 \%$. However, the 272 useful questionnaires found to be in line with the recommendation of (Saunders, Lewis, \& Thornhill, 2009). Sample size is larger than the minimum required for a significant level $(\alpha=0.05)$ is 97 (Cohen \& Whitten, 1980). The response rate was similar to previous studies in the field of green supply chain management for example (Eltayeb, Zailani, \& Ramayah, 2011; Gimenez, Sierra, \& Rodon, 2012; Wong, Lai, Shang, Lu, \& Leung, 2012). Table 1 shows the composition of sample.

\subsection{Measurement development}

To examine the hypothesis, the theoretical construct was adopted from the existing scales. The construct of market, non-market stakeholders are adopted from (Lawrence, 2010) and construct of regulatory stakeholders was drawn from the research studies of (Buysse \& Verbeke, 2003; Henriques \& Sadorsky, 1999). A five point Likert scale was used to collect the information from respondents and asked to "indicate the extent to which did 
Mediation analysis of environmental training: Stakeholder pressure and supply chain management practices

your firm consider perceive influence from different stakeholders in adopting green supply chain management practices" where 5 represents 'very strongly', 4 'relatively strong', 3 'to some degree', 2 'a little bit', and 1 'not at all, to evaluate the conceptually develop and validate measurement model in different facets of adoption of green supply management practices in the organization. Market stakeholders, usually involved in direct, economic transactions with the enterprise and they play a critical role in its value chain (Lawrence, 2010). In this study market stakeholders are defined those who are directly involved in supply chain and in economic transactions with the firm. On the other side, Non-market stakeholders are those who do not have direct economic transactions with the firm, but have significantly on the economic transactions (Lawrence, 2010).

\section{Table 1}

Sample Characteristics

\begin{tabular}{|c|c|c|}
\hline Firm Size & Total & Percentage \\
\hline Number of employees less than 50 & 66 & $0.24 \%$ \\
\hline Between 50 and 250 employees & 134 & $0.49 \%$ \\
\hline Number of employees greater than 250 & 72 & $0.26 \%$ \\
\hline & Total & \\
\hline \multicolumn{3}{|l|}{ Industrial Sector } \\
\hline Leather manufacturers & 56 & $0.21 \%$ \\
\hline Surgical instruments & 106 & $0.39 \%$ \\
\hline Sports Good Industry & 97 & $0.35 \%$ \\
\hline others & 13 & $0.04 \%$ \\
\hline \multicolumn{3}{|l|}{ Title of respondents } \\
\hline Chief executive officer & 82 & $0.30 \%$ \\
\hline Director operations & 68 & $0.25 \%$ \\
\hline Manager Purchasing & 52 & $0.19 \%$ \\
\hline Manager import and export & 70 & $0.26 \%$ \\
\hline \multicolumn{3}{|l|}{ Years of experience } \\
\hline$>3$ years $<$ & 73 & $0.27 \%$ \\
\hline Between 3 and 10 years & 169 & $0.62 \%$ \\
\hline 10 years $<$ & 30 & $0.11 \%$ \\
\hline
\end{tabular}

Non-market stakeholders' questions items involved government Regulations, Non-governmental organization, mass media, and environmental pressure groups. The regulatory stakeholders have the ability to influence on the firm operations (Henriques \& Sadorsky, 1999). The concept of green supply chain management is centered on environmental aspects of a firm and its ability to manage its process and relationship the life cycle of SCM (Wolf, 2011). The scale and items of internal and external green supply chain practices are adopted from the studies of (Yang, Lin, Chan, \& Sheu, 2010; Zhu et al., 2008). Using previous research work (Giovanni, 2012; Vachon \& Klassen, 2006). ESCM activities with suppliers and customers were considered. A five point Likert scale is used to collect the information from respondents and asked to assess to what extent your firm has developed the following green supply chain management practices, where 5-implementing fully, 4- Initiating implementation, 3- considering it currently, 2- planning to consider it, 1-Not considering it. Internal green supply chain management practices includes implementation of Environmental management system, eco-design for product and process, source reduction and cross functional collaborations for improvement of environmental performance are defined as implementation of environmental management practices within a company (Rao \& Holt, 2005; Vachon \& Klassen, 2006; Zhu et al., 2008).

External environmental activities related to cooperation and integrating with supply chain partner and sourcing renewable material. It define as direct involvement of firm for jointly planning for GSCM practices with its suppliers and customers (Vachon \& Klassen, 2006; Walton et al., 1998). Following the guidelines of past research, the environmental training was adopted from the studies of (de Jabbour, Jabbour, Latan, Teixeira, \& de Oliveira, 2015; Sarkis et al., 2010). A five point Likert scale was used to collect the information from respondents and asked "to indicate the frequency to which your firm provides environmental related training to your employees" where 5-Never, 4- Very rarely, 3- Rarely, 2- Occasionally, 1-frequently.The statistical software 


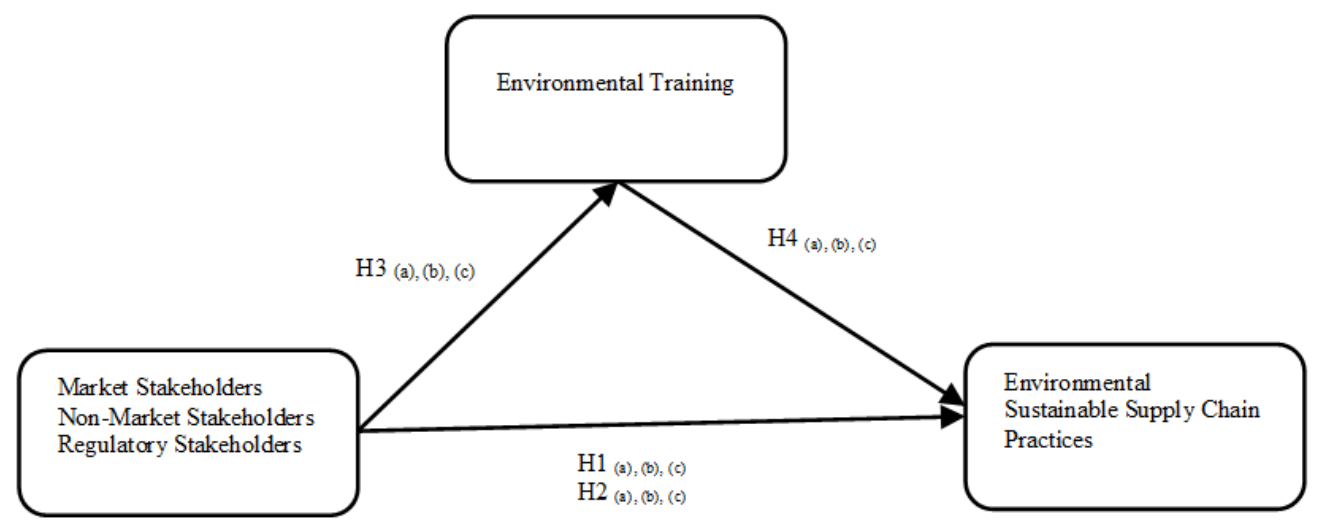

Figure 1. Proposed model

\section{Data analysis and results}

The collected data was tested for normality distribution through applying the skewness and kurtosis statistics test (Cohen, Cohen, West, \& Aiken, 2003). The assumption of normality distribution of the data is violated if values of kurtosis and skewness exceeded absolute value 2 and 7 respectively (Hair, Black, Babin, \& Anderson, 2010). In the present study, the skewness and kurtosis values were found to be 1.89 and 1.71 respectively, suggests univariate normality. The results showed no deviation from the normality assumption of the data and revealed the present data is normally distributed. The values of the kurtosis fall within the required range. Multi-collinearity was assessed by examining variance inflation factor (VIF) and values fall between 1.63 to 2.01, suggests no multi-collinearity issue (Hair et al., 2010).

\subsection{Factor analysis}

Factor analysis is a statistical method aims to identify the relationship between the multiple observed and unobserved variables and has been used in operations management research (Shah \& Goldstein, 2006). Two types of factor analysis: Exploratory Factor Analysis (EFA) and Confirmatory Factor Analysis (CFA) (Hair et al., 2010). EFA used to explore the between the large number of measurement variables and it is assume that any variable may be linked with other measurement variable. CFA check whether the measurement items of construct really associated with that construct not the other construct (Tabachnick, Fidell, \& Osterlind, 2001). Factor analysis test was used to extract the number of useful items to be used for the survey questionnaires, purify the measurement, and measure the dimensionality. Principal component method with Varimax rotation was used to condense the factor items into a certain factors. Reliability of the data checked through employing the inter-item correlation and Cranach's Alpha value. The value of Kaiser-Myer-Olkin (KMO) is 0.843, and Bartlett sphericity test is significant at $p<0.01$.

The reliability of the data were checked using the Cronbach's alpha, it shows that to what extent to which internal consistence of the data findings are accurately reflect phenomena under investigated (Collis \& Hussey, 2013). The structured equation modeling (SEM) was used to test the goodness of fit test through using confirmatory factor analysis. This test shows that either model met the required minimum specifications. For a good model test, the minimum specification of all the independent variables need to have three statements with factor loading values greater than 0.70. It is important to note that this test do not establish the particular paths within the model were significant. For this study factor loadings 0.70 or above was selected of a specific factor. Factors items inter-correlation less than 0.5 considered unreliable for further data analysis (Hair et al., 2010). The reliability value of Cronbach's alpha is considered high if a value is greater than 0.70 and if a value smaller than 
Mediation analysis of environmental training: Stakeholder pressure and supply chain management practices

0.3 this shows that item has low reliability. According to Hair et al. (2010) factor value 0.70 or above is regarded reliable and implies that it has high reliability. Chi square value is significant in conjunction with other values which also indicate the model is bet fit and adequate for the data analysis. Chi square value is sensitive to the sample size and adequate sample size for using structured equation modeling is 200.The accepted value of the chi square to the degree of freedom must fall within the range of 2 to 5 (Marsh, Balla, \& McDonald, 1988).

\subsection{Validity and Reliability: Confirmatory Factor Analysis}

To measure the reliability and validity of measurement model, confirmatory factor analysis (CFA) test was conducted because present scales of items adopted from the previous studies. Overall, 6 factor model provides overall fit to the data and CFA results in terms of descriptive statistics. The absolute and incremental measures of fit statics of model chi square $=2.17$, Residual root mean square (RMSEA) $=0.053$, goodness of fit indices $=.907$, $\mathrm{CFI}=.910, \mathrm{NFI}=.956, \mathrm{NFFI}=.961$. The absolute and incremental value meets the cut-off score of these measures (Bollen, 1989; Gerbing \& Anderson, 1992).

The results of the analysis are presented in Table 2, internal consistency measures are commonly applied, the Cronbach's alpha $(\alpha)$ and the composite reliability. As it can be seen in the Table 2, values of composite reliability and Cronbach's alpha $(\alpha)$ exceed the 0.8 threshold value of internal consistency (Nunnally \& Bernstein, 1994), thus indicating construct reliability. Convergent validity is degree to which construct should share a high proportion of variance (Hair et al., 2010) and expressed by the average variance extracted(AVE) and value exceed 0.5 is considered a good indicator of convergent validity. Table 2 reports all the values for the construct exceed 0.5, suggests adequate convergent validity (Bentler \& Bonett, 1980). Convergent validity was also tested with the Bentler-Bonett Normed Fit Index (NFI) and it measures the extent to which different approaches measure the same results and value above 0.90 provide strong evidence for the convergent validity. NFI is difference between the chi-square value of Null model and chi-square value of specified hypothesized model (Bentler \& Bonett, 1980).

According to the Bagozzi and Phillips (1982) discriminant validity refers to as extent to which a construct and indicators are different from other constructs and items and it can be measured in different ways. Discriminant validity compared the chi-square value between the constrained and unconstrained model. Discriminate validity refers to construct is empirically and conceptually distinct (Anderson \& Gerbing, 1988). In unconstrained model, correlations set to 1 and. The results shows unconstrained model is better fit (see table 3). The unconstrained model shows a better fit than the constrained model and chi-square test is significant $(p<0.001)$. Squared of AVE is greater than the squared multiple correlations of all the items (see table 4). Taken together, the results show that theoretical construct has good psychometric properties.

\subsection{Tests for Non-response and Common Method Variance}

In this present study, data collected using key informant approach from targeted firms. The respondents were selected who had an experience in dealing with the export related issues. The respondents had an average of 5 years of experience in the firms and were serving in middle level management and higher management positions. Many previous studies have adopted this approach to collect data from the middle and upper level management and is consisted with the existing research (Vachon \& Klassen, 2006; Zhu, Sarkis, \& Lai, 2013, 2007). The test of non-response bias was conducted to assess whether early response received and later received are significantly different are not. First the collected survey response was compared with those which received later using the $\mathrm{t}$-test between the two groups, (1) earlier respondents and (2) late respondents. The t-test shows that the survey response collected earlier and received later at 5\% significance level in all items. The result of t-tests does not show any significant difference between the two groups of respondents on firm size, and respondent industrial experience. This consistent with the result findings of (Zhu et al., 2007). The key informant approach for data collection from multiple sources within each organization can reduce the impact of the common method bias (Marshall, McCarthy, Heavey, \& McGrath, 2015). 
Awan, U.

Table 2

Construct Validity and Reliability

\begin{tabular}{|c|c|c|c|c|c|c|c|}
\hline Factors/Items & Mean & SD & Loadings & t-Value & AVE & $\mathrm{CR}$ & $\alpha$ \\
\hline Market Stakeholders (MS) & & & & & .574 & 0.80 & .79 \\
\hline Customer Pressure & 4.29 & 1.61 & 0.76 & 11.02 & & & \\
\hline International Supplier pressure & 3.84 & 1.83 & 0.81 & 09.15 & & & \\
\hline Employees Pressure & 4.27 & 1.54 & 0.70 & 12.65 & & & \\
\hline Non-Market Stakeholders (NMS) & & & & & .514 & 0.80 & .79 \\
\hline Media Pressure ( Print and electronic) & 4.01 & 1.48 & .76 & 16.25 & & & \\
\hline Society Pressure & 3.94 & 1.69 & .74 & 18.11 & & & \\
\hline Community Organization & 3.99 & 1.29 & .61 & 13.95 & & & \\
\hline Environmental NGOs & 3.06 & 1.77 & .75 & 17.64 & & & \\
\hline Regulatory Pressure (RP) & & & & & 0.617 & 0.867 & .85 \\
\hline Central and local government & 3.45 & 1.42 & .82 & 21.51 & & & \\
\hline Trade Associations & 2.72 & 1.63 & .75 & 17.29 & & & \\
\hline Financial Regulators & 2.48 & 1.47 & .78 & 18.94 & & & \\
\hline International Laws and Regulators & 2.95 & 1.64 & .80 & 22.57 & & & \\
\hline Environmental Training (EM) & & & & & 0.615 & 0.865 & .85 \\
\hline Training is focus on use of Techniques for eco design & 3.24 & 1.90 & .79 & 15.84 & & & \\
\hline $\begin{array}{l}\text { Training on recycling of material and disposal of } \\
\text { production waste }\end{array}$ & 2.73 & 1.83 & .76 & 19.80 & & & \\
\hline $\begin{array}{l}\text { Training related to ISO } 14001 \text { or other environmental } \\
\text { management system }\end{array}$ & 3.63 & 1.97 & .82 & 20.50 & & & \\
\hline $\begin{array}{l}\text { Training on use of cutting edge techniques to manage } \\
\text { solid waste }\end{array}$ & 4.05 & 1.93 & .77 & 21.75 & & & \\
\hline $\begin{array}{c}\text { External environmental Supply Chain Management } \\
\text { Practices (EISCMP) }\end{array}$ & & & & & 0.601 & 0.90 & 0.90 \\
\hline Suppliers' ISO14000 certification & 4.24 & 1.73 & .77 & 16.94 & & & \\
\hline Cooperation with customers for cleaner production & 3.50 & 1.59 & .79 & 20.35 & & & \\
\hline Cooperation with customers for green packaging & 2.30 & 1.88 & .81 & 21.50 & & & \\
\hline Cooperation with customer for eco-design & 3.15 & 1.69 & .78 & 18.70 & & & \\
\hline Suppliers are selected using environmental criteria & 4.80 & 1.69 & .82 & 15.60 & & & \\
\hline Require suppliers to use environmental packaging & 2.63 & 1.54 & .75 & 18.80 & & & \\
\hline $\begin{array}{c}\text { Internal environmental Supply Chain Management } \\
\text { Practices (IESCMP) }\end{array}$ & & & & & .595 & 0.898 & .89 \\
\hline $\begin{array}{l}\text { Taking environmental criteria into consideration Special } \\
\text { training for workers on environmental issues }\end{array}$ & 4.13 & 1.87 & .79 & 17.62 & & & \\
\hline $\begin{array}{l}\text { Design of products to avoid or reduce use of hazardous of } \\
\text { products and/or their manufacturing process }\end{array}$ & 4.60 & 1.63 & .74 & 19.68 & & & \\
\hline $\begin{array}{l}\text { Design of products for reuse, recycle, recovery of } \\
\text { material, component parts }\end{array}$ & 2.80 & 1.97 & .80 & 21.50 & & & \\
\hline Design of processes form minimization of waste & 3.45 & 1.96 & .80 & 19.68 & & & \\
\hline Produces products that have reused or recycled materials & 2.89 & 1.88 & .77 & 16.16 & & & \\
\hline $\begin{array}{l}\text { Establishes recycling systems into manufacturing } \\
\text { processes }\end{array}$ & 4.38 & 1.95 & .73 & 18.55 & & & \\
\hline
\end{tabular}

Table 3

Results of unconstrained model

\begin{tabular}{|c|c|c|c|c|c|c|c|}
\hline & Factors & 1 & 2 & 3 & 4 & 5 & 6 \\
\hline 1 & Market Stakeholders & & & & & & \\
\hline 2 & Non-Market Stakeholders & 52.41 & & & & & \\
\hline 3 & Regulatory Stakeholders & 42.19 & 62.08 & & & & \\
\hline 4 & Environmental Management Training & 56.68 & 112.3 & 55.31 & & & \\
\hline 5 & Internal ESCM practices & 29.86 & 125.60 & 64.26 & 122.16 & & \\
\hline 6 & External ESCM practices & 55.49 & 130.56 & 41.94 & 132.69 & 72.88 & \\
\hline
\end{tabular}

To validate the market, non-market and regulatory stakeholders are different constructs, exploratory factor analysis (EFA) conducted and each item loaded for separately as proposed. Further discriminate. Further, to assess whether any alternative and possible combination of market and non-market stakeholders measure 
Mediation analysis of environmental training: Stakeholder pressure and supply chain management practices

provides a better fit than the hypothesized model. Vanishing tetrad test (VTT) approach compares SEM model based covariance of indicators and the product of other pair of covariance. Tetrad refers to the "difference between the product of a pair of covariance and the product of another pair among four random variables" (Bollen \& Ting, 2000).

\section{Table 4}

Items Correlations

\begin{tabular}{|c|c|c|c|c|c|c|c|}
\hline & Factors & 1 & 2 & 3 & 4 & 5 & 6 \\
\hline 1 & Market Stakeholders & .757 & & & & & \\
\hline 2 & Non-Market Stakeholders & .66 & .716 & & & & \\
\hline 3 & Regulatory Stakeholders & .46 & .41 & .785 & & & \\
\hline 4 & Environmental Management Training & .34 & .53 & .57 & .784 & & \\
\hline 5 & Internal ESCM practices & .32 & .38 & .64 & .54 & .755 & \\
\hline 6 & External ESCM practices & .56 & .26 & .39 & .46 & .28 & .771 \\
\hline
\end{tabular}

The guidelines of Bollen and Ting (2000) was followed for testing VTT, first specify the relationship between the latent variable and indicators,(2) vanishing tetrad implied for each model,(3) adjust vanishing tetrads by eliminating redundant,(4) simultaneously perform VTT. In order to apply VTT, implied covariance matrix was derived from AMOS, provide output similar to asymptotic distribution with number of degree of for (Wilson, Callaghan, \& Stainforth, 2007) used VTT approach and proposed the different level of brand personality within a range of broader brand relationship equal to non-redundant test. VTT has largely been overlooked (Bollen, Lennox, \& Dahly, 2009). Using VTT, In this presents study, null hypothesis fails to reject and results reveals that market, non-market and regulatory stakeholders are separate construct $(\chi 2=, 0.3 .11, \mathrm{df}=3$, $p=0.73$ ).It provide clearly evident that the model is adequate fit the data (and provide support to the model (Ting, 1995).

\subsection{Common Method Bias}

The potential of common method bias (CMB) is threat to the data validity since data was collected at a single point (Gimenez et al., 2012). Three approaches were used to assess the common method bias. In the first approach, all questionnaires items were placed in different parts of the questionnaires. In the second approach the respondents and companies anonymity were protected and in the third step, a statistical technique Harman's single factor. The low results of model fit suggest that the common method variance is not a problem. This approach is in line with the (Conway \& Lance, 2010; Gimenez et al., 2012). To avoid from the threat of common method bias, the guidelines of (Podsakoff, MacKenzie, Lee, \& Podsakoff, 2003) was followed to evaluate this potential problem, this approach has also been used in the study of (Zhu et al., 2012) and (Lai, Wong, \& Cheng, 2012). According to Podsakoff and Organ (1986) if common method bias exist, a single factor emerge during the factor analysis, which account a majority of variance than other factors.

In present study, un-rotated factor analysis results reveals that first factor captures only $23.3 \%$ of the variance in the data, suggested that common method bias might not be an issue. In statistical approach among other statistical remedies are available to control the effect of CMB, the most common approach is used is Harman's single factor test (Malhotra, Kim, \& Patil, 2006). This approach is used with the exploratory factor analysis (EFA).This approach is used when there exist a single factor emerge from un-rotated factor or majority of the covariance is explained by the first factor (Podsakoff et al., 2003). Six factors accounting 63.14\% of variance at Eigen value $>1$. This shows that CMB is unlikely to affect the results of the study. Harmon's one factor test was used to assess whether the common method bias is problem for this study or not. The CMB further was assessed based on the recommendation (Podsakoff et al., 2003) with Harman's one-factor test. For this, all items are loaded on one factor and confirmatory factor analysis results showed a poor fit of the model and a single factor did not emerge which accounted the most of the variance (normed chi-square, $\chi^{2} / \mathrm{df}=4.06$, 
Awan, U.

Goodness of fit indices, $(\mathrm{GFI})=0.681$, Comparative Fit indices $(\mathrm{CFI})=0.635$, Root mean square error of approximation $(\mathrm{RMSEA})=0.170$, standardized root mean square residual $(\mathrm{SRMR})=0.143$. Thus results shows that it is unlikely to confound the problem of CMB.

\subsection{Hypothesis Testing}

Having assessing the measurement model in the previous section, the resulted data is now in a reliable form and structured equation modeling (SEM) can be used to test the hypothesize developed for this study. For determine hypothesize, the path coefficient level was used for evaluating the results. Significance level was set 0.05 and 0.01 for this study to test hypothesize. If the significance value is equal or greater than the 0.05 , the hypothesis was rejected, otherwise it was accepted. The SEM approach was used to examine the strength of relationship among the research constructs and hypotheses in order to identify latent variables in the conceptual model and determine the direction of these relationships (Baumgartner \& Homburg, 1996).

The survey result provides the strong evidence for validating the conceptual model in the context of the manufacturing context. The result shows that significant and insignificant relationship of e-service quality with the customer retention. The results of paths coefficient (see table 5) shows that the all the construct have significant factor loading and demonstrate good level of Cronbach's alpha greater than 0.7. The path constructs of direct and indirect relationship as shown in the table 6.

Table 5

Results of Paths Coefficient

\begin{tabular}{lcc}
\multicolumn{1}{c}{ Paths } & Coefficients & t-Statistics \\
\hline Firm Size $\rightarrow$ Internal Green SCMP & -0.09 & 1.138 \\
Firm Size $\rightarrow$ External Green SCMP & -0.13 & 1.261 \\
Industry $\rightarrow$ Internal Green SCMP & 0.36 & 6.268 \\
Industry $\rightarrow$ External Green SCMP & 0.29 & 7.524 \\
Market Stakeholder pressure $\rightarrow$ Internal environmental SCMP & 0.39 & 6.241 \\
Non-Market Stakeholder pressure $\rightarrow$ Internal green SCMP & 0.14 & 1.174 \\
Regulatory Stakeholder pressure $\rightarrow$ Internal green SCMP & 0.41 & 7.652 \\
Market Stakeholder pressure $\rightarrow$ External environmental SCMP & 0.19 & 6.584 \\
Non-Market Stakeholder pressure $\rightarrow$ External environmental SCMP & 0.11 & 1.013 \\
Regulatory Stakeholder pressure $\rightarrow$ External environmental SCMP & 0.39 & 5.968 \\
Market Stakeholder pressure $\rightarrow$ Environmental Training & 0.35 & 5.534 \\
Non- Stakeholder pressure $\rightarrow$ Environmental Training & 0.16 & 3.032 \\
Regulatory Stakeholder pressure $\rightarrow$ Environmental Training & 0.43 & 5.917 \\
Environmental Training $\rightarrow$ Internal environmental & 0.22 & 5.887 \\
Environmental Training $\rightarrow$ External environmental SCMP & 0.40 & 6.455
\end{tabular}

In particular, as hypothesized, the results of path analysis reveals, there is significant positive association between the market stakeholders pressure and adoption of internal and external ESCM practices $(b=0.39$, $\mathrm{t}=6.241, p<0.01)$ and $(\mathrm{b}=0.19, \mathrm{t}=6.584, p<0.01)$ respectively. Support was found for H1a and H2a. However, the $\mathrm{H} 1 \mathrm{a}$ and $\mathrm{H} 2 \mathrm{~b}$ shows a positive relationship between the non-market stakeholder and adoption of internal and external ESCM practices, was not found statistical significant $(b=0.14, t=1.174, p<0.01)$ and $(b=0.11, t=1.013$, $p<0.01)$ respectively.

Further, support was found for the regulatory stakeholders significantly $\mathrm{H} 1 \mathrm{c}$ and $\mathrm{H} 2 \mathrm{c}$ positively influence on the adoption of the internal and external ESCM practices $(b=0.41, t=7.652, p<0.01)$ and $(b=0.39, t=5.968$, $p<0.01$ ). The hypothesis linking the market $\mathrm{H} 3 \mathrm{a}$, non-market $\mathrm{H} 3 \mathrm{~b}$ and regulatory stakeholders $\mathrm{H} 3 \mathrm{c}$ to environmental training were all significant and in the desired expected direction. The path leading to environmental training from market stakeholders $\mathrm{H} 3 \mathrm{a},(\mathrm{b}=0.35, \mathrm{t}=5.534, p<0.05)$, non-market stakeholders $\mathrm{H} 3 \mathrm{~b}$ $(\mathrm{b}=0.16, \mathrm{t}=5.917, p<0.05)$ and regulatory stakeholders $\mathrm{H} 3 \mathrm{c}(\mathrm{b}=0.43, \mathrm{t}=5.917, p<0.05)$ respectively. 
Mediation analysis of environmental training: Stakeholder pressure and supply chain management practices

Furthermore, significant relationship was found linking hypothesis to internal and external ESCM practices from environmental training (ET). The path leading to internal and external GSCM from ET; H4a $(b=0.22$, $\mathrm{t}=5.887, p<0.05)$ and $\mathrm{H} 4 \mathrm{a}(\mathrm{b}=0.40, \mathrm{t}=6.455, p<0.05)$ respectively. In addition to this, the path coefficient for the control variable, results shows a negatively and insignificant relationship exist between the firm size and adoption of internal and external $\operatorname{ESCM}(b=-0.09, \mathrm{t}=1.138, p<0.00)$ and $(b=-0.13, \mathrm{t}=1.261, p<0.01)$ respectively. For the control variable of industry type a statistically significant relationship was found in adoption of internal and external ESCM $(b=-0.36, t=6.268, p<0.00)$ and $(b=0.29, t=6.268, p<0.01)$. The $\mathrm{R}^{2}$ values of the environmental training and internal and external ESCM are $0.526,0.712$ and 0.755 respectively.

\section{Table 6}

Results of mediation analysis based on Structural Equation Modeling

\begin{tabular}{|c|c|c|c|c|}
\hline Structural Paths & Model 1 & Model 2 & Model 3 & Model 4 \\
\hline Market Stakeholder pressure $\rightarrow$ Environmental Training & $0.56^{* *}$ & $0.60 * *$ & $0.56^{* *}$ & \\
\hline Regulatory Stakeholder pressure $\rightarrow$ Environmental Training & $0.43 * *$ & $0.49 *$ & $0.45^{* *}$ & \\
\hline Environmental Training $\rightarrow$ Internal environmental SCMP & $0.29 *$ & $0.34 * *$ & $0.25 * *$ & \\
\hline Environmental Training $\rightarrow$ External environmental SCMP & $0.40 * *$ & $0.46 * *$ & $0.33 * *$ & \\
\hline Market Stakeholder pressure $\rightarrow$ Internal environmental SCMP & $0.39 * *$ & & $0.34 * *$ & $0.34 * *$ \\
\hline Market Stakeholder pressure $\rightarrow$ External environmental SCMP & $0.19 * *$ & $\ldots$ & $0.17 * *$ & $0.17 * *$ \\
\hline Regulatory Stakeholder pressure $\rightarrow$ Internal environmental SCMP & $0.41 *$ & $\ldots$ & $0.36 * *$ & $0.36 * *$ \\
\hline Regulatory Stakeholder pressure $\rightarrow$ External environmental SCMP & $0.39 *$ & & $0.36 * *$ & $0.36 * *$ \\
\hline \multicolumn{5}{|l|}{ Model Fit Statistics } \\
\hline $\mathrm{X}^{2}$ & 1635.362 & 1667.842 & 1644.609 & 1688.544 \\
\hline df & 596 & 598 & 598 & 593 \\
\hline RMSEA & 0.062 & 0.062 & 0.053 & 0.069 \\
\hline AGFI & 0.821 & 0.821 & 0.821 & 0.813 \\
\hline CFI & 0.966 & 0.952 & 0.966 & 0.922 \\
\hline NFI & 0.911 & 0.911 & 0.911 & 0.899 \\
\hline NNFI & 0.936 & 0.924 & 0.936 & 0.910 \\
\hline PNFI & 0.723 & .723 & 0.723 & 0.711 \\
\hline AIC & 344.63 & 353.20 & 342.09 & 348.06 \\
\hline CAIC & 577.08 & 581.73 & 571.99 & 586.67 \\
\hline $\mathrm{R}^{2}$ ( Internal Green supply chain management) & 0.62 & 0.67 & 0.68 & 0.67 \\
\hline $\mathrm{R}^{2}$ (External Green supply chain management) & 0.58 & 0.64 & 0.65 & 0.64 \\
\hline
\end{tabular}

Note. Model 1 = Proposed hypothesized model. Model 2 = Full mediation model. Model 3 = Partial mediation model

Model 4 = Direct model. *t-values significant at $p<0.05$, **t-values significant at $p<0.01$.

Akaike information criterion (AIC). SCMP = supply chain management practice.

The proposed full structure model was tested using the structural equation modeling. The maximum likelihood method was used as parameter estimation. A mediation effect test was performed using the structural equation modeling approach on recommendation of (James, Mulaik, \& Brett, 2006) to test the mediation analysis. Hypothesis relationship was tested using t-statics (Hair et al., 2010). The summary of result statics are presented in Table (Mediation results). The model 1 (see table 6) reports the results of all hypothesis except the mediation effect of the environmental training. Full mediation model 2 include the paths from the regulatory stakeholders and market stakeholders to environmental management training and from environmental management training to internal and external green supply chain management practices. The results for full mediation model reveals that the environmental management mediates the link between the market stakeholders, regulatory stakeholders and internal and external ESCM.A partial mediation model 3 was also evaluated to check extent to which ET fully or partially mediates the relationship between the predictors and internal and external ESCM. In model 3, direct paths also adds from the regulatory and market stakeholders to internal and external ESCM, suggesting ET partially mediates the relationship between the regulatory and market stakeholder and internal and external ESCM.

A number of author suggest the use of Akaike's Information Criterion (AIC) (Akaike, 1987) is a good indicator for comparison of model quality (Collins, Fidler, Wugalter, \& Long, 1993) with (Bozdogan, 1987) consistent Version of the AIC and Corrected Akaike's Information Criterion (CAIC) (see Table-Mediation).The AIC commonly related to the degree of freedom reflecting to number of estimated parameter and it does not 
Awan, U.

consider the sample size, however, CAIC takes sample sizes into accounts (Bandalos, 1993). The present study takes into account the both values for model comparison, smaller values representing a better fit to the model (Hu, Bentler, \& Hoyle, 1995). AIC and CAIC values reveal a good model fit (see table 6). Turning to the output in Table mediation, the statistics value for the partial mediation model are smaller than they are for other models. The results clearly indicate that the model 3 is better than the full mediation model 2.

The direct link between the market stakeholders to internal was found to be significant $(b=0.39, t=6.15$, $p<0.01)$ and external GSCM external $(\mathrm{b}=0.19, \mathrm{t}=7.96, p<0.01)$, provide support that the effect of market stakeholder on Internal and external GSCM partially mediates through ET. The direct link between the regulatory stakeholders to internal was found to be significant $(b=0.41, t=8.60, p<0.01)$ and external GSCM external $(b=0.39, t=9.63, p<0.01)$, provide support that the effect of market stakeholder on Internal and external GSCM partially mediates through ET. Thus, compare to the fully mediation model and partial mediation model, confirm ET mediates the relationship between market and regulatory stakeholders and internal and external GSCM.

\section{Conclusion}

The study focused on revealing the stakeholder pressure and examines the mediating role of the environmental training. The finding of mediation analysis provide support for the notion that environmental training found was found to partially mediates the relationship between the market and regulatory stakeholders and implementation of the green supply chain management practices.

The study demonstrates two important findings. First, the market stakeholders and regulatory governance pressure is both important for the implementation of environmental supply chain management practices. Second, when environmental training is used, there will be greater implementation of ESCM initiatives than when the stakeholder governance mechanism as pressure is used separately. It is also concluded that the regulatory governance may be one important but may need to be combined with the market stakeholder role for achieving greater effectiveness of sustainability initiatives. The successful management of stakeholder pressure may led to offer more learning, and ultimately making them capable to take into consideration implementation and evaluation of social issues into supply chain and ultimately its impact on social performance. The mediation analysis suggests that, effective governance mechanism that can be employed by manufacturing firms to manage their environmental operations.

The mediation analysis further revealed that the market stakeholder pressure is not only highly relevant but also interrelated. Thus, market and regulatory stakeholder pressure is mainly contributed to manufacturing firm's implementation of ESCM practices. Specifically, where stakeholder pressure is low, environmental training programs might not be helpful in capturing the essence of such outcomes in South Asian countries. The result suggests that priority should be given to manage quality of coordination for environmental related training programs to improve successfully implementation of environmental supply chain practices.

In summary, the study findings support the notion that market stakeholders mainly contributes to the implementation of ESCM practices, but also mediated through environmental training programs by the manufacturing firms. Finally, the results of study indicate that implementation of ESCM practices lies in the resources firm creates and is enhanced by both market and regulatory stakeholders' pressure.

\subsection{Limitations, future research and implications}

The study is not without limitation, despite the study advances the literature by describing it with the stakeholders and resource base view perspective. The present study collect data from the firm side, in future research study is needed that collect the data from the stakeholders and firms to capture the potential areas which requires immediate attention to improve the sustainability. Although environmental training programs plays an essential role, a future research is need to test whether training programs on implementation of social 
Mediation analysis of environmental training: Stakeholder pressure and supply chain management practices

sustainability initiative could serve as mediates in other industry with different regulatory and geographic conditions. Furthermore, the present study did not find support for the non-market stakeholder. Future research study needed to examine how non-market stakeholder can play their active role for the sustainability initiatives. A key managerial implication for the international buyers is to recognize that if they apply environmental sustainability related practices to the firms, it is unlikely they will be fully implemented. In such a way, stakeholder pressure is a good way to implementation of these practices in South Asia; however manager could rely on environmental training programs, for effective implementation of such initiatives. From a practical perspective, to further enhance implementation, firms can also use environmental training programs and findings suggest that environmental training program is the primary governance mechanism for international buyers in South Asia.

\section{References}

Ageron, B., Gunasekaran, A., \& Spalanzani, A. (2012). Sustainable supply management: An empirical study. International Journal of Production Economics, 140(1), 168-182. http://doi.org/10.1016/j.ijpe.2011.04.007

Ahmad, S., \& Schroeder, R. G. (2003). The impact of human resource management practices on operational performance: Recognizing country and industry differences. Journal of Operations Management, 21(1), 19-43. http://doi.org/10.1016/S0272-6963(02)00056-6

Akaike, H. (1987). Factor analysis and AIC. Psychometrika, 52(3), 317-332.

Anderson, J. C., \& Gerbing, D. W. (1988). Structural equation modeling in practice: A review and recommended two-step approach. Psychological Bulletin, 103(3), 411.

Arlbjørn, J. S., \& Lüthje, T. (2012). Global operations and their interaction with supply chain performance. Industrial Management \& Data Systems, 112(7), 1044-1064. http://doi.org/10.1108/02635571211255014

Azizullah, A., Khattak, M. N. K., Richter, P., \& Häder, D.-P. (2011). Water pollution in Pakistan and its impact on public health: A review. Environment International, 37(2), 479-497.

Bagozzi, R. P., \& Phillips, L. W. (1982). Representing and testing organizational theories: A holistic construal. Administrative Science Quarterly, 27(3), 459-489.

Bandalos, D. L. (1993). Factors influencing cross-validation of confirmatory factor analysis models. Multivariate Behavioral Research, 28(3), 351-374.

Barney, J. (1991). Firm resources and sustained competitive advantage. Journal of Management, 17(1), 99-120. http://doi.org/10.1177/014920639101700108

Baumgartner, H., \& Homburg, C. (1996). Applications of structural equation modeling in marketing and consumer research: A review. International Journal of Research in Marketing, 13(2), 139-161.

Becchetti, L., \& Santoro, M. I. M. (2001). The determinants of small and medium-sized firm internationalization and its relationship with productive efficiency. Review of World Economics, 137(2), 297-319.

Bentler, P. M., \& Bonett, D. G. (1980). Significance tests and goodness of fit in the analysis of covariance structures. Psychological Bulletin, 88(3), 588.

Betts, T. K., Wiengarten, F., \& Tadisina, S. K. (2015). Exploring the impact of stakeholder pressure on environmental management strategies at the plant level: What does industry have to do with it? Journal of Cleaner Production, 92, 282-294. http://doi.org/10.1016/j.jclepro.2015.01.002

Bhattacharya, A., Mohapatra, P., Kumar, V., Dey, P. K., Brady, M., Tiwari, M. K., \& Nudurupati, S. S. (2014). Green supply chain performance measurement using fuzzy ANP-based balanced scorecard: A collaborative decision-making approach. Production Planning \& Control, 25(8), 698-714. http://doi.org/10.1080/09537287.2013.798088

Birkinshaw, J., Hamel, G., Mol, M. J., \& Vaccaro, I. (2008). Management innovation. Academy of Management Review, 33(4), 825-845. http://doi.org/10.5465/AMR.2008.34421969

Björklund, M., Martinsen, U., \& Abrahamsson, M. (2012). Performance measurements in the greening of supply chains. Supply Chain Management: An International Journal, 17(1), 29-39. 
http://doi.org/10.1108/13598541211212186

Bollen, K. A. (1989). A new incremental fit index for general structural equation models. Sociological Methods \& Research, 17(3), 303-316.

Bollen, K. A., Lennox, R. D., \& Dahly, D. L. (2009). Practical application of the vanishing tetrad test for causal indicator measurement models: An example from health-related quality of life. Statistics in Medicine, 28(10), 1524-1536.

Bollen, K. A., \& Ting, K. (2000). A tetrad test for causal indicators. Psychological Methods, 5(1), 3-22.

Bozdogan, H. (1987). Model selection and Akaike's information criterion (AIC): The general theory and its analytical extensions. Psychometrika, 52(3), 345-370.

Buysse, K., \& Verbeke, A. (2003). Proactive environmental strategies: A stakeholder management perspective. Strategic Management Journal, 24(5), 453-470.

Carter, C. R., \& Carter, J. R. (1998). Interorganizational determinants of environmental purchasing: Initial evidence from the consumer products industries. Decision Sciences, 29(3), 659-684. http://doi.org/10.1111/j.1540-5915.1998.tb01358.x

Carter, C. R., \& Easton, P. L. (2012). Sustainable supply chain management: Evolution and future directions. International Journal of Physical Distribution \& Logistics Management, 41(1), 46-62. http://doi.org/10.1108/09600031111101420

Chien, M. K., \& Shih, L.-H. (2007). An empirical study of the implementation of green supply chain management practices in the electrical and electronic industry and their relation to organizational performances. International Journal of Environmental Science and Technology, 4(3), 383-394.

Clarkson, M. E. (1995). A stakeholder framework for analyzing and evaluating corporate social performance. Academy of Management Review, 20(1), 92-117.

Cohen, A. C., \& Whitten, B. J. (1980). Estimation in the three-parameter lognormal distribution. Journal of the American Statistical Association, 75(370), 399-404.

Collins, L. M., Fidler, P. L., Wugalter, S. E., \& Long, J. D. (1993). Goodness-of-fit testing for latent class models. Multivariate Behavioral Research, 28(3), 375-389.

Collis, J., \& Hussey, R. (2013). Business research: A practical guide for undergraduate and postgraduate students. Palgrave Macmillan.

Conway, J. M., \& Lance, C. E. (2010). What reviewers should expect from authors regarding common method bias in organizational research. Journal of Business and Psychology, 25(3), 325-334.

de Sousa Jabbour, A. B. L., Jabbour, C. J. C., Govindan, K., Kannan, D., Salgado, M. H., \& Zanon, C. J. (2013). Factors affecting the adoption of green supply chain management practices in Brazil: empirical evidence. International Journal of Environmental Studies, 70(2), 302-315.

Delmas, M. A., \& Toffel, M. W. (2010). Institutional pressures and organizational characteristics: implications for environmental strategy. Harvard Business School Technology \& Operations Management Unit. Working Paper, 11-050.

Diabat, A., \& Govindan, K. (2011). An analysis of the drivers affecting the implementation of green supply chain management. Resources, Conservation and Recycling, 55(6), 659-667. http://doi.org/10.1016/j.resconrec.2010.12.002

Diane, H., \& Abby, G. (2009). An empirical study of green supply chain management practices amongst UK manufacturers. Journal of Manufacturing Technology Management, 20(7), 933-956. http://doi.org/10.1108/17410380910984212

Dillman, D. A. (2011). Mail and Internet surveys: The tailored design method. Update with new internet, visual, and mixed-mode guide. John Wiley \& Sons.

Ditlev-Simonsen, C. D., \& Wenstøp, F. (2013). How stakeholders view stakeholders as CSR motivators. Social Responsibility Journal, 9(1), 137-147.

Donaldson, T., \& Preston, L. E. (1995). The stakeholder theory of the corporation: Concept. Academy of Management Review, 20(1), 65-91. http://doi.org/10.5465/amr.1995.9503271992

Ehrgott, M., Reimann, F., Kaufmann, L., \& Carter, C. R. (2011). Social sustainability in selecting emerging economy suppliers. Journal of Business Ethics, 98(1), 99-119. 
Mediation analysis of environmental training: Stakeholder pressure and supply chain management practices

ElTayeb, T. K., Zailani, S., \& Jayaraman, K. (2010). The examination on the drivers for green purchasing adoption among EMS 14001 certified companies in Malaysia. Journal of Manufacturing Technology Management, 21(2), 206-225. http://doi.org/10.1108/17410381011014378

Eltayeb, T. K., Zailani, S., \& Ramayah, T. (2011). Green supply chain initiatives among certified companies in Malaysia and environmental sustainability: Investigating the outcomes. Resources, Conservation and Recycling, 55(5), 495-506. http://doi.org/10.1016/j.resconrec.2010.09.003

Eltayeb, T., Zailani, S., \& Ramayah, T. (2011). Influences of green supply chain management practices on organizational sustainable performance. Resources, Conservation and Recycling, 1(1), 12-23.

Esteban-Lloret, N. N., Aragón-Sánchez, A., \& Carrasco-Hernández, A. (2014). Institutional and competitive drivers on managers' training and organizational outcomes. Business Research Quarterly, 17(4), 242-258. http://doi.org/10.1016/j.brq.2014.03.003

Foley, J. A., DeFries, R., Asner, G. P., Barford, C., Bonan, G., Carpenter, S. R., ... et al. (2005). Global consequences of land use. Science, 309(5734), 570-574.

Freeman, R. E., Harrison, J. S., Wicks, A. C., Parmar, B., \& Colle, S. de. (2010). Stakeholder theory: The state of the art. Cambridge University Press.

Genovese, A., Lenny Koh, S. C., Kumar, N., \& Tripathi, P. K. (2013). Exploring the challenges in implementing supplier environmental performance measurement models: A case study. Production Planning \& Control, 25(13-14), 1198-1211. http://doi.org/10.1080/09537287.2013.808839

Gerbing, D. W., \& Anderson, J. C. (1992). Monte Carlo evaluations of goodness of fit indices for structural equation models. Sociological Methods \& Research, 21(2), 132-160.

Gimenez, C., Sierra, V., \& Rodon, J. (2012). Sustainable operations: Their impact on the triple bottom line. International Journal of Production Economics, 140(1), 149-159. http://doi.org/10.1016/j.ijpe.2012.01.035

Giovanni, P. De. (2012). Do internal and external environmental management contribute to the triple bottom line? International Journal of Operations \& Production Management, 32(3), 265-290. http://doi.org/10.1108/01443571211212574

Gonzalez-Benito, J., \& Gonzalez-Benito, O. (2006). The role of stakeholder pressure and managerial values in the implementation of environmental logistics practices. International Journal of Production Research, 44(7), 1353-1373. http://doi.org/10.1080/00207540500435199

González-Benito, J., \& González-Benito, Ó. (2010). A study of determinant factors of stakeholder environmental pressure perceived by industrial companies. Business Strategy and the Environment, 19(3), 164-181. http://doi.org/10.1002/bse.631

Gunasekaran, A., \& Gallear, D. (2012). Special issue on sustainable development of manufacturing and services. International Journal of Production Economics, 140(1), 1-6.

Hair, J. F. J., Black, W. C., Babin, B. J., \& Anderson, R. E. (2010). Multivariate data analysis (7 ${ }^{\text {th }}$ ed.). Prentice Hall.

Henriques, I., \& Sadorsky, P. (1999). The relationship between environmental commitment and managerial perceptions of stakeholder importance. Academy of Management Journal, 42(1), 87-99. https://doi.org/10.2307/256876

Hervani, A., Helms, M. M., \& Sarkis, J. (2005). Performance measurement for green supply chain management. Benchmarking: An International Journal, 12, 330-353. https://doi.org/10.1108/14635770510609015

Hu, L.-T., Bentler, P. M., \& Hoyle, R. H. (1995). Evaluating model fit. In R. H. Hoyle (Ed.), Structural equation modeling: Concepts, issues, and applications (pp. 76-99). Thousand Oaks, CA: Sage.

Hult, G. T. M., Mena, J. a., Ferrell, O. C., \& Ferrell, L. (2011). Stakeholder marketing: a definition and conceptual framework. AMS Review, 1(1), 44-65. https://doi.org/10.1007/s13162-011-0002-5

Jabbour, A. B. L. de S., Jabbour, C. J. C., Latan, H., Teixeira, A. A., \& de Oliveira, J. H. C. (2015). Reprint of "Quality management, environmental management maturity, green supply chain practices and green performance of Brazilian companies with ISO 14001 certification: Direct and indirect effects." Transportation Research Part E: Logistics and Transportation Review, 74, 139-151. https://doi.org/10.1016/j.tre.2014.12.011 
Awan, U.

Jabbour, C. J. C., \& De Sousa Jabbour, A. B. L. (2016). Green human resource management and green supply chain management: Linking two emerging agendas. Journal of Cleaner Production, 112, 1824-1833. https://doi.org/10.1016/j.jclepro.2015.01.052

James, L. R., Mulaik, S. A., \& Brett, J. M. (2006). A tale of two methods. Organizational Research Methods, 9(2), 233-244. https://doi.org/10.1177/1094428105285144

Kanapathy, K., Yee, G. W., Zailani, S., \& Aghapour, A. H. (2016). An intra-regional comparison on RoHS practices for green purchasing management among electrical and electronics SMEs in Southeast Asia. International Journal of Procurement Management, 9(3), 249-271. https://doi.org/10.1504/IJPM.2016.076304

Lai, K. H., Wong, C. W. Y., \& Cheng, T. C. E. (2012). Ecological modernisation of Chinese export manufacturing via green logistics management and its regional implications. Technological Forecasting and Social Change, 79(4), 766-770. http://doi.org/10.1016/j.techfore.2011.10.004

Laosirihongthong, T., Adebanjo, D., \& Choon Tan, K. (2013). Green supply chain management practices and performance. Industrial Management \& Data Systems, 113(8), 1088-1109. http://dx.doi.org/10.1108/IMDS-04-2013-0164

Lawrence, A. T. (2010). Managing disputes with nonmarket stakeholders: Wage a fight, withdraw, wait, or work it out? California Management Review, 53(1), 90-113. http://doi.org/10.1525/cmr.2010.53.1.90

Lee, S.-Y., Klassen, R. D., Furlan, A., \& Vinelli, A. (2014). The green bullwhip effect: Transferring environmental requirements along a supply chain. International Journal of Production Economics, 156, 39-51. http://dx.doi.org/10.1016/j.ijpe.2014.05.010

Liu, Y. (2009). Investigating external environmental pressure on firms and their behavior in Yangtze River Delta of China. Journal of Cleaner Production, 17(16), 1480-1486. http://doi.org/10.1016/j.jclepro.2009.05.010

Malhotra, N. K., Kim, S. S., \& Patil, A. (2006). Common method variance in IS research: A comparison of alternative approaches and a reanalysis of past research. Management Science, 52(12), 1865-1883. http://dx.doi.org/10.1287/mnsc.1060.0597

Marsh, H. W., Balla, J. R., \& McDonald, R. P. (1988). Goodness-of-fit indexes in confirmatory factor analysis: The effect of sample size. Psychological Bulletin, 103(3), 391-410. http://dx.doi.org/10.1037/0033-2909.103.3.391

Marshall, D., McCarthy, L., Heavey, C., \& McGrath, P. (2015). Environmental and social supply chain management sustainability practices: construct development and measurement. Production Planning \& Control, 26(8), 673-690. http://doi.org/10.1080/09537287.2014.963726

Meixell, M. J., \& Luoma, P. (2015). Stakeholder pressure in sustainable supply chain management: A systematic review. International Journal of Physical Distribution \& Logistics Management, 45(1-2), 69-89. http://dx.doi.org/10.1108/IJPDLM-05-2013-0155

Melnyk, S. A., Sroufe, R. P., \& Calantone, R. (2003). Assessing the impact of environmental management systems on corporate and environmental performance. Journal of Operations Management, 21(3), 329-351. http://doi.org/10.1016/S0272-6963(02)00109-2

Mitra, S., \& Datta, P. P. (2014). Adoption of green supply chain management practices and their impact on performance: an exploratory study of Indian manufacturing firms. International Journal of Production Research, 52(7), 2085-2107. http://dx.doi.org/10.1080/00207543.2013.849014

Mohanty, R. P., \& Prakash, A. (2013). Green supply chain management practices in India: An empirical study. Production Planning \& Control, 25(16), 1322-1337. http://doi.org/10.1080/09537287.2013.832822

Nunnally, J. C., \& Bernstein, I. H. (1994). The assessment of reliability. Psychometric Theory, 3(1), $248-292$.

Odeyale, S. O., Oguntola, A. J., \& Odeyale, E. O. (2013). Evaluation and selection of an effective green supply chain management strategy: A case study. International Journal of Research Studies in Management, 3(1).27-39 10. https://doi.org/5861/ijrsm.2013.550

Paauwe, J., \& Boselie, P. (2003). Challenging "strategic HRM"and the relevance of the institutional setting. Human Resource Management Journal, 13(3), 56-70. https://doi.org/10.1111/j.1748-8583.2003.tb00098.x 
Mediation analysis of environmental training: Stakeholder pressure and supply chain management practices

Palmberg, K., \& Garvare, R. (2006). Sustained quality management: How to receive the Swedish quality award twice. International Journal of Quality \& Reliability Management, 23(1), 42-59. http://doi.org/10.1108/02656710610637541

Parmigiani, A., Klassen, R. D., \& Russo, M. V. (2011). Efficiency meets accountability: Performance implications of supply chain configuration, control, and capabilities. Journal of Operations Management, 29(3), 212-223. http://doi.org/10.1016/j.jom.2011.01.001

Podsakoff, P. M., MacKenzie, S. B., Lee, J.-Y., \& Podsakoff, N. P. (2003). Common method biases in behavioral research: a critical review of the literature and recommended remedies. Journal of Applied Psychology, 88(5), 879. http://dx.doi.org/10.1037/0021-9010.88.5.879

Podsakoff, P. M., \& Organ, D. W. (1986). Self-reports in organizational research: Problems and prospects. Journal of Management, 12(4), 531-544. https://doi.org/10.1177/014920638601200408

Ramirez, E., Gonzalez, R. J., \& Moreira, G. J. (2014). Barriers and bridges to the adoption of environmentally-sustainable offerings. Industrial Marketing Management, 43(1), 16-24. http://doi.org/10.1016/j.indmarman.2013.07.012

Rao, P., \& Holt, D. (2005). Do green supply chains lead to competitiveness and economic performance? International Journal of Operations \& Production Management, 25(9), 898-916. http://doi.org/10.1108/01443570510613956

Rouf, K. A. (2013). Ecological economics to protect the planet from ecocide and free people from iron cage consumerism. International Journal of Research Studies in Management, 3(1), 83-94. https://doi.org/10.5861/ijrsm.2013.300

Sambasivan, M., Bah, S. M., \& Ho, J. A. (2013). Making the case for operating "green": Impact of environmental proactivity on multiple performance outcomes of Malaysian firms. Journal of Cleaner Production, 42, 69-82. http://doi.org/10.1016/j.jclepro.2012.11.016

Sarkis, J., Gonzalez-Torre, P., \& Adenso-Diaz, B. (2010). Stakeholder pressure and the adoption of environmental practices: The mediating effect of training. Journal of Operations Management, 28(2), 163-176. http://doi.org/10.1016/j.jom.2009.10.001

Sarkis, J., Zhu, Q., \& Lai, K. H. (2011). An organizational theoretic review of green supply chain management literature. International Journal of Production Economics, 130(1), 1-15. http://doi.org/10.1016/j.ijpe.2010.11.010

Saunders, M., Lewis, P., \& Thornhill, A. (2009). Research methods for business students (5th ed.). In M. Saunders, P. Lewis, \& A. Thornhill (Eds.), Understanding research philosophies and approaches (pp. 106-136). Edinburg Gate, Harlow: Pearson Education.

Shah, R., \& Goldstein, S. M. (2006). Use of structural equation modeling in operations management research: Looking back and forward. Journal of Operations Management, 24(2), 148-169.

Sharma, S., \& Henriques, I. (2005). Stakeholder influences on sustainability practices in the Canadian forest products industry. Strategic Management Journal, 26(2), 159-180. http://doi.org/10.1002/smj.439

Srivastava, S. K. (2007). Green supply-chain management: a state-of-the-art literature review. International Journal of Management Reviews, 9(1), 53-80. https://doi.org/10.1111/j.1468-2370.2007.00202.x

Tabachnick, B. G., Fidell, L. S., \& Osterlind, S. J. (2001). Using multivariate statistics $\left(4^{\text {th }}\right.$ ed.). Needham Heights, Ma.: Allyn and Bacon.

Tachizawa, E. M., \& Wong, C. Y. (2015). The performance of green supply chain management governance mechanisms: A supply network and complexity perspective. Journal of Supply Chain Management, 51(3), 18-32. http://doi.org/10.1111/jscm.12072

Teixeira, A. A., Jabbour, C. J. C., de Sousa Jabbour, A. B. L., Latan, H., \& de Oliveira, J. H. C. (2014). Green training and green supply chain management: Evidence from Brazilian firms. Journal of Cleaner Production, 116, 170-176. http://doi.org/10.1016/j.jclepro.2015.12.061

Ting, K.-F. (1995). Confirmatory tetrad analysis in SAS. Structural Equation Modeling: A Multidisciplinary Journal, 2(2), 163-171. http://dx.doi.org/10.1080/10705519509540005

Trade Fair. (2011). Learning about fair trade. South Asia focus: Child labour and human rights.

Tsai, W.-H., \& Hung, S.-J. (2009). A fuzzy goal programming approach for green supply chain optimisation 
Awan, U.

under activity-based costing and performance evaluation with a value-chain structure. International Journal of Production Research, 47(18), 4991-5017. http://dx.doi.org/10.1080/00207540801932498

Vachon, S., \& Klassen, R. D. (2006). Extending green practices across the supply chain: The impact of upstream and downstream integration. International Journal of Operations \& Production Management, 26(7), 795-821. http://doi.org/10.1108/01443570610672248

Walker, H., Di Sisto, L., \& McBain, D. (2008). Drivers and barriers to environmental supply chain management practices: Lessons from the public and private sectors. Journal of Purchasing and Supply Management, 14(1), 69-85. http://doi.org/10.1016/j.pursup.2008.01.007

Walton, S. V, Handfield, R. B., \& Melnyk, S. A. (1998). The green supply chain: integrating suppliers into environmental management processes. International Journal of Purchasing \& Materials Management, 34(2), 2-11. https://doi.org/10.1111/j.1745-493X.1998.tb00042.x

Wicks, A. C., Gilbert, D. R., \& Freeman, R. E. (1994). A feminist interpretation of the stakeholder concept. Business Ethics Quarterly, 4(4), 475-497. http://doi.org/10.2307/3857345

Wilson, B., Callaghan, W., \& Stainforth, G. (2007). An application of vanishing tetrad analysis to a brand model. International Review of Business Research Papers, 3(2), 456-485.

Wolf, J. (2011). Sustainable supply chain management integration: A qualitative analysis of the German manufacturing industry. Journal of Business Ethics, 102(2), 221-235. http://doi.org/10.1007/s10551-011-0806-0

Wolf, J. (2014). The relationship between sustainable supply chain management, stakeholder pressure and corporate sustainability performance. Journal of Business Ethics, 119(3), 317-328. http://doi.org/10.1007/s10551-012-1603-0

Wong, C. W. Y., Lai, K. H., Shang, K. C., Lu, C. S., \& Leung, T. K. P. (2012). Green operations and the moderating role of environmental management capability of suppliers on manufacturing firm performance. International Journal of Production Economics, 140(1), 283-294. http://doi.org/10.1016/j.ijpe.2011.08.031

Wong, C. Y., Wong, C. W. Y., \& Boon-itt, S. (2015). Integrating environmental management into supply chains: a systematic literature review and theoretical framework. International Journal of Physical Distribution \& Logistics Management, 45(1/2), 43 - 68. http://doi.org/doi.org/10.1108/IJPDLM-05-2013-0110

Wu, Z., \& Pagell, M. (2011). Balancing priorities: Decision-making in sustainable supply chain management. Journal of Operations Management, 29(6), 577-590. http://doi.org/10.1016/j.jom.2010.10.001

Yan, M. R., Chien, K. M., \& Yang, T. N. (2016). Green component procurement collaboration for improving supply chain management in the high technology industries: A case study from the systems perspective. Sustainability, 8(2), 1-16. http://doi.org/10.3390/su8020105

Yang, C. L., Lin, S. P., Chan, Y. H., \& Sheu, C. (2010). Mediated effect of environmental management on manufacturing competitiveness: An empirical study. International Journal of Production Economics, 123(1), 210-220. http://doi.org/10.1016/j.ijpe.2009.08.017

Zhu, Q., Geng, Y., Fujita, T., \& Hashimoto, S. (2010). Green supply chain management in leading manufacturers: Case studies in Japanese large companies. Management Research Review, 33(4), 380-392. http://doi.org/10.1108/01409171011030471

Zhu, Q., \& Sarkis, J. (2007). The moderating effects of institutional pressures on emergent green supply chain practices and performance. International Journal of Production Research, 45(18-19), 4333-4355. http://doi.org/10.1080/00207540701440345

Zhu, Q., Sarkis, J., Cordeiro, J. J., \& Lai, K.-H. (2008). Firm-level correlates of emergent green supply chain management practices in the Chinese context. Omega, 36(4), 577-591. http://doi.org/10.1016/j.omega.2006.11.009

Zhu, Q., Sarkis, J., \& Lai, K. (2008). Confirmation of a measurement model for green supply chain management practices implementation. International Journal of Production Economics, 111(2), 261-273. http://doi.org/10.1016/j.ijpe.2006.11.029

Zhu, Q., Sarkis, J., \& Lai, K. (2012). Examining the effects of green supply chain management practices and their mediations on performance improvements. International Journal of Production Research, 50(5), 
Mediation analysis of environmental training: Stakeholder pressure and supply chain management practices

1377-1394. http://dx.doi.org/10.1080/00207543.2011.571937

Zhu, Q., Sarkis, J., \& Lai, K. (2013). Institutional-based antecedents and performance outcomes of internal and external green supply chain management practices. Journal of Purchasing and Supply Management, 19(2), 106-117. http://doi.org/10.1016/j.pursup.2012.12.001

Zhu, Q., Sarkis, J., \& Lai, K. hung. (2007). Initiatives and outcomes of green supply chain management implementation by Chinese manufacturers. Journal of Environmental Management, 85(1), 179-189. http://doi.org/10.1016/j.jenvman.2006.09.003

Zhu, Q., Tian, Y., \& Sarkis, J. (2012). Diffusion of selected green supply chain management practices: an assessment of Chinese enterprises. Production Planning \& Control, 23(10-11), 837-850. http://doi.org/10.1080/09537287.2011.642188

Zhu, Q., Zhu, Q., Sarkis, J., \& Geng, Y. (2005). Green supply chain management in China: pressures, practices and performance. International Journal of Operations \& Production Management, 25, 449-468. http://doi.org/10.1108/01443570510593148 
Awan, U. 